\title{
RET/TRIM33 Fusion Gene
}

National Cancer Institute

\section{Source}

National Cancer Institute. RET ITRIM33 Fusion Gene. NCI Thesaurus. Code C99855.

A fusion gene that results from a chromosomal translocation $t(1 ; 10)(p 13 ; q 11)$ which fuses the 5 ' portion of the RET gene and the 3' portion of the TRIM33 gene. This rearrangement is associated with papillary thyroid carcinoma. 